\title{
Evaluation of Proximate and Mineral Composition of Biscuit Formulated Using Chayote (Sechium edule) and Mung Bean (Vigna radiata) Flours
}

\author{
Jamaludin M. Sakung ${ }^{1 *}$, Siti Nuryanti ${ }^{2}$, Afadil Afadil ${ }^{3}$, Sri Hastuti Virgianti Pulukadang ${ }^{3}$, Maryam Maryam ${ }^{3}$, Mar'atun Mar'atun $^{3}$
}

${ }^{1}$ Department of Health Biochemistry, Faculty of Teacher Training and Education, Tadulako University, City of Palu, Indonesia; ${ }^{2}$ Faculty of Teacher Training and Education, Tadulako University, City of Palu, Indonesia; ${ }^{3}$ Chemistry Education, Faculty of Teacher Training and Education, Tadulako University, City of Palu, Indonesia

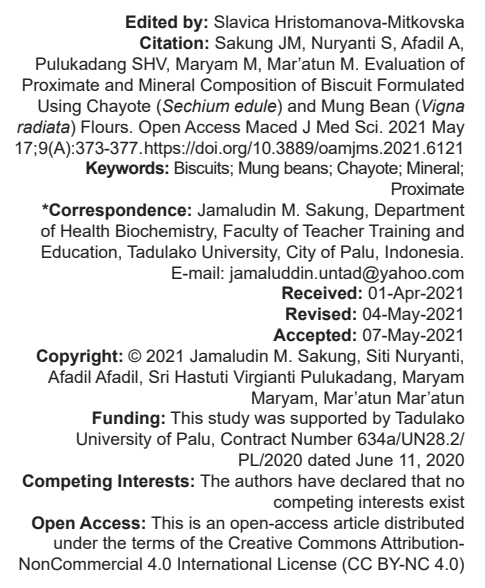

Introduction

Biscuits are the most common dried food product consumed by the public. The consumption of biscuits per capita in Indonesia continues to increase; in 2015 , the rate was 18.406 ounces $/ 0.1 \mathrm{~kg}$, and in 2018 it was 24.22 ounces $/ 0.1 \mathrm{~kg}$, with the number of consumers estimated at around $5 \%-8 \%$ of the entire population [1], [2]. The development of biscuit products to be used as health foods could help to prevent various degenerative diseases and improve public health [3]. Chayote and mung beans in flour form could replace whole wheat flour used to make biscuits to increase health benefits and reduce dependence on imported processed food products such as wheat flour [4], [5].

Chayote is an abundant source of nutrients, including dietary fiber, essential minerals, vitamins, and amino acids [6]. Mung beans are a source of vegetable protein. Furthermore, every $100 \mathrm{~g}$ contains $323 \mathrm{kcal}$ of energy, $22.9 \mathrm{~g}$ of protein (19.5-33.1\%), $1.5 \mathrm{~g}$ of fat, $56.8 \mathrm{~g}$ of carbohydrates, $223 \mathrm{mg}$ of calcium, $319 \mathrm{mg}$ of phosphorus, $7.5 \mathrm{mg}$ of iron, $223 \mathrm{ug}$ of total carotene, $0.46 \mathrm{mg}$ of thiamine, $0.15 \mathrm{mg}$ of riboflavin, $1.5 \mathrm{mg}$ niacin, and $10 \mathrm{mg}$ Vitamin C [7], [8]. Innovation is required to manufacture processed food products while preserving the high nutritional content of chayote and mung beans and managing their short storage capacity. Moreover, ideally, these products should be both ready-to-eat and contribute to disease prevention [9], [10].

Mung bean flour has a high nutritional composition including carbohydrates (56.43 $\pm 0.16 \%)$, fiber $(4.95 \pm 0.08 \%)$ fat $(1.53 \pm 0.04 \%)$, and protein $(23.84 \pm 0.04 \%)$ [11]. The nutritional composition of chayote flour includes ash $(4.49 \pm 0.17 \%)$, carbohydrates $(73.35 \pm 0.47 \%)$, fat $(3.49 \pm 0.29 \%)$, and protein $(15.10$ $\pm 0.27 \%$ ) [12]. Their high nutritional composition makes them ideal for developing as products or processing into flour for use in other products. This innovation involves a simple food process that results in raw material for making biscuit products.

Chayote and mung beans are high-quality ingredients, and their flour may be used to produce biscuits with special health-enhancing characteristics. 
Determining the physical and chemical properties of a new food product is an essential part of the development process. The basic determination of carbohydrates, fats, proteins, ash, and mineral content indicates their nutritional value. It should be noted, however, that this changes value depending on the mixture of raw materials used to make the product. Materials and processing methods may also change the nutritional composition of biscuits that use this flour as a substitute for wheat flour [13], [14], [15].

The nutritional quality evaluation of chayote and mung bean biscuits as a new food formulation is related to nutrition guidelines and food intake requirements. Due to their high nutritional properties, these biscuits may be used as part of a feeding program in disaster situations such as famine or earthquakes [15]. Determination of nutritional quality is inexpensive and relatively easy to do using processes such as proximate or macro nutrition analysis, which will assess the main components of the biscuits, including ash, water, carbohydrates, fat, and protein. Mineral or micronutrient analysis can also be performed to evaluate levels of potassium, sodium, calcium, and iron [16]

\section{Methods}

This research was pre-experimental. The biscuit samples were divided into five formulations based on the ratio of chayote flour and mung bean flour (\%) (Table 1). This research has four different stages of work, including preparing the chayote flour, preparing the mung bean flour, and making the biscuits. Finally, proximate and mineral analyses on the final product were then carried out.

Table 1: Biscuit formulation made from chayote and mung beans flour

\begin{tabular}{|c|c|c|c|c|c|}
\hline \multirow{2}{*}{ Ingredients } & \multicolumn{5}{|c|}{ Product formulation } \\
\hline & F1 (100:0) & F2 (75:25) & F3 (50:50) & F4 (25:75) & F5 $(0: 100)$ \\
\hline Chayote flour (g) & 100 & 75 & 50 & 25 & 0 \\
\hline Mung beans flour (g) & 0 & 25 & 50 & 75 & 100 \\
\hline Butter & 170 & 170 & 170 & 170 & 170 \\
\hline $\begin{array}{l}\text { Sucralose (Diabetasol Zero } \\
\text { Calorie Sweetener) }(\mathrm{g})\end{array}$ & 100 & 100 & 100 & 100 & 100 \\
\hline Milk powder (g) & 30 & 30 & 30 & 30 & 30 \\
\hline $\begin{array}{l}\text { Vanilla synthetic } \\
\text { powder (tsp) }\end{array}$ & $1 / 2$ & $1 / 2$ & $1 / 2$ & $1 / 2$ & $1 / 2$ \\
\hline Eggs & 1 & 1 & 1 & 1 & 1 \\
\hline
\end{tabular}

\section{Flour preparation}

The materials used in this process were chayote and mung beans (obtained from smallholder plantations in Central Sulawesi) and clean water. The process of preparing the chayote flour was begun by removing the chayote skin, washing it, and cutting into small pieces. The mung beans were soaked for $1 \times 24 \mathrm{~h}$ and then placed in an oven at $105^{\circ} \mathrm{C}$ for $2 \times 24 \mathrm{~h}$. After this, they were powdered and sieved using an 80 -mesh stainless filter.

\section{Preparation for making biscuits}

The main ingredients of the product formulation were chayote and mung bean flour. Additional components included butter, Sucralose, powdered milk, vanilla, chicken eggs, and water (Table 1).

\section{Biscuit formulation development}

Two hundred grams of flour (chayote and mung bean flour with the formulation of 100:0, 75:25, 50:50, $25: 75,0: 100)$ were sifted. Thirty grams of powdered milk were added to the same container, stirring until flour and powdered milk were mixed. One hundred seventy grams butter, $100 \mathrm{~g}$ powdered Sucralose, one egg yolk, and $1 / 2$ teaspoon vanilla powder were then added. All ingredients were thoroughly mixed using an electric mixer. The dough was shaped, placed on an oven plate that had been smeared with margarine. The dough was heated in an oven at $160^{\circ} \mathrm{C}$ for $15-20 \mathrm{~min}$, taken out, and cooled. Biscuits made of chayote and mung bean flour were then ready for proximate analysis (moisture, ash, carbohydrate, fat, and protein content) and mineral analysis (sodium, potassium, calcium, and iron content).

\section{Proximate analysis}

Evaluation of the proximate composition, that is, moisture content, was conducted using the thermogravimetric method, the ash content was analyzed using the dry ashing method, and the fat content was evaluated using the Soxhlet method. Protein analysis was analyzed using the ultraviolet-visible spectrophotometric method. The total carbohydrate content measurement in a sample was calculated based on the calculation (in $\%)$. Furthermore, the percentage of carbohydrate content was calculated by $100 \%$ minus the cumulative percentage of protein, fat, ash, and water content [4].

\section{Mineral analysis}

Evaluation of the mineral composition, including Potassium (K), Calcium (Ca), Sodium $(\mathrm{Na})$, and Iron $(\mathrm{Fe})$, was carried out using the atomic absorption spectrophotometer method. First, $1 \mathrm{~mL}$ of the sample solution was made. It was then diluted with water in a $50 \mathrm{~mL}$ volumetric flask until the mark limit. The potassium, calcium, sodium, and iron levels in the sample solution were determined by measuring their absorption with an atomic absorption spectrophotometer. Potassium was measured at a wavelength of $766.5 \mathrm{~nm}$, calcium was measured at a wavelength of $589 \mathrm{~nm}$, sodium was measured at a wavelength of $285.2 \mathrm{~nm}$, and ferrous was measured at a wavelength $6280 \mathrm{~nm}$ [4]. 


\section{Results and Discussion}

\section{Proximate composition}

Proximate analysis of chayote and mung bean biscuit formulations (Table 2) obtained the lowest and highest water contents of $2.118 \%$ and $5.298 \%$ for F5 and F3, respectively. The formula (50:50) of chayote and mung beans increased water content due to the biscuits' high protein content. The highest ash content obtained was $2.87 \%$ in $\mathrm{F} 1$ (100\% biscuits from chayote flour) and the lowest was $1.42 \%$ in F5 (100\% biscuits from mung bean flour). The highest carbohydrate content obtained was $59.88 \%$ in $\mathrm{F} 5$ and the lowest was $53.68 \%$ in $\mathrm{F} 2$. The highest fat content obtained was $32.64 \%$ in $\mathrm{F} 1$ and the lowest was $24.33 \%$ in F5. The highest protein content obtained was $12.25 \%$ in $\mathrm{F} 5$ and the lowest was $5.65 \%$ in $\mathrm{F} 1$.

Table 2: Proximate composition of biscuit products

\begin{tabular}{llllll}
\hline Parameters & \multicolumn{5}{c}{ Biscuit formulation of chayote and mung bean flours $(\mathrm{g} / 100 \mathrm{~g})$} \\
\cline { 2 - 6 } & $\mathrm{F} 1(100: 0)$ & $\mathrm{F} 2(75: 25)$ & $\mathrm{F} 3(50: 50)$ & $\mathrm{F} 4(25: 75)$ & $\mathrm{F} 5(0: 100)$ \\
\hline Water & $2.68 \pm 0.01$ & $4.91 \pm 0.29$ & $5.30 \pm 0.60$ & $5.16 \pm 0.01$ & $2.12 \pm 0.00$ \\
Ash & $2.87 \pm 0.01$ & $2.56 \pm 0.03$ & $2.02 \pm 0.02$ & $1.96 \pm 0.04$ & $1.42 \pm 0.03$ \\
Carbohydrate & $56.16 \pm 0.06$ & $53.68 \pm 0.32$ & $55.62 \pm 0.44$ & $59.01 \pm 0.29$ & $59.88 \pm 0.65$ \\
Fat & $32.64 \pm 0.39$ & $28.22 \pm 0.14$ & $27.63 \pm 0.00$ & $26.13 \pm 0.08$ & $24.33 \pm 0.29$ \\
Protein & $5.65 \pm 0.32$ & $10.62 \pm 0.14$ & $9.44 \pm 0.14$ & $7.75 \pm 0.35$ & $12.25 \pm 0.34$ \\
\hline${ }^{2}$ Mean \pm SD for 2 replications. & & & &
\end{tabular}

The water composition in a portion of food is an indicator of quality; high water content leads food products to have a short shelf life due to microbes or microorganisms [17], [18], [19]. The chayote and mung bean formulated biscuits have a low moisture content, which indicates that they would have a long shelf life. Based on the Indonesian national standard, the maximum ash content of biscuits is $1.6 \%$. The mung bean biscuits met these requirements, so it would be advisable to heat to $525-550^{\circ} \mathrm{C}$ to obtain good quality biscuits with a high mineral content [20], [21].

The highest value of carbohydrate content was in $\mathrm{F} 5$ due to the higher carbohydrate content in mung bean flour than in chayote flour. In this study, the carbohydrate content of the biscuits decreased by replacing wheat flour with mung bean and chayote flours. The low carbohydrate content of chayote flour was the reason for the decreasing of the carbohydrate content in the biscuits. Mung beans are a primary source of carbohydrates after rice and wheat and have a low glycemic index [22]. Consuming mung bean biscuits may control the incidence of type 2 diabetes mellitus [23]. This study also supports mung bean flour biscuits as a better $\mathrm{CHO}$ source for irritable bowel syndrome patients. They are more likely to help to prevent the occurrence of diabetes mellitus compared to rice and wheat [23], [24].

The high-fat content of chayote was the reason for the high-fat content in the biscuits formulated with chayote and mung bean flour. Chayote flour and mung bean flour each contain 3.49\% [12] and 1.43\% [25] of fat, respectively. Biscuits with low-fat content contribute to energy density and are significantly affected by food processing [26]. Biscuits made from mung bean flour or a $100 \%$ formulation of mung bean flour as a basic ingredient contained high protein as mung beans are a plant-based food that is rich in protein [27]. The protein content in mung bean flour affects the dough's strength, meaning that biscuit products with an interesting texture and appearance would be obtained [22]. The protein content $(5.65-12.25 \%)$ of chayote and mung bean biscuits added value to these food products, with protein content sufficient enough that these biscuits could increase protein intake in children and adults [28], [29].

\section{Mineral evaluation of biscuits}

The mineral analysis of chayote and mung bean biscuit formulation (Table 3) obtained the highest potassium content of $429.12 \%$ in F5, while the lowest was $142.22 \%$ in $\mathrm{F} 1$. The highest calcium content obtained was $69 \%$ in F5 $(100 \%$ biscuits from mung bean flour), and the lowest was $26.8 \%$ in F2. The highest sodium content obtained was $417.39 \%$ in $\mathrm{F} 5$ and the lowest was $169.68 \%$ in $\mathrm{F} 1$. The highest iron content obtained was $14.06 \%$ in $\mathrm{F} 5$ and the lowest was $0.73 \%$ in $\mathrm{F} 1$.

Table 3: Mineral composition of biscuit formulations

\begin{tabular}{|c|c|c|c|c|c|}
\hline \multirow[t]{2}{*}{ Parameter } & \multicolumn{5}{|c|}{ Biscuit formulation of chayote and mung beans flour $(\mathrm{g} / 100 \mathrm{~g})$} \\
\hline & F1 (100:0) & F2 (75:25) & F3 (50:50) & F4 (25:75) & F5 $(0: 100)$ \\
\hline Potassium (K) & $142.22 \pm 15.50$ & $312.03 \pm 1.79$ & $353.17 \pm 2.69$ & $379.12 \pm 2.69$ & $429.12 \pm 1.79$ \\
\hline Calcium (Ca) & $36.80 \pm 0.57$ & $26.80 \pm 0.57$ & $34.00 \pm 0.57$ & $39.40 \pm 0.57$ & $69.00 \pm 0.28$ \\
\hline Sodium ( $\mathrm{Na})$ & $169.68 \pm 1.01$ & $265.37 \pm 0.20$ & $341.09 \pm 1.22$ & $382.04 \pm 2.23$ & $417.39 \pm 1.42$ \\
\hline Iron $(\mathrm{Fe})$ & $0.73 \pm 0.15$ & $2.61 \pm 0.15$ & $4.38 \pm 0.30$ & $9.06 \pm 0.14$ & $14.06 \pm 0.44$ \\
\hline
\end{tabular}

In the mineral analysis, potassium was found to have the highest levels in the formulation of chayote and mung bean biscuits (1:1) at $353.17 \%$ compared to sodium $(341.09 \%)$, calcium $(34.0 \%)$, and iron $(4.38 \%)$. The high value of potassium levels in all biscuit formulations makes the development of biscuit products potentially suitable as a health food to prevent hypertension [30], [31]. Potassium is the most intracellular electrolyte solution and plays a role in fluid balance and osmotic pressure [32]. Potassium and sodium are necessary to transmit nerve impulses and muscle contractions. Deficiency symptoms include diarrhea, vomiting, diabetic acidosis, and severe malnutrition [33]. Sodium is the second most abundant mineral in chayote and mung bean biscuits. The sodium value contribution in the biscuits $(1: 1)$ comes from the basic ingredient of mung bean flour, which has a sodium content value of $5.47 \%$ [34]. The calcium and iron content of the biscuits $(1: 1)$ formulated with chayote and mung beans were $34.0 \%$ and $4.38 \%$, respectively. Compared to the results reported by Onwurafor et al. [35], this value was higher in biscuits formulated with mung beans and unripe Raja banana flour at $32.34 \%$ and $3.98 \%$, respectively. Instant powdered nutritional content qualified by the Indonesian National Standard nutrient was protein, 
fiber, and water content. Energy and fat were lower, but carbohydrates were high [36].

\section{Conclusions}

Chayote and mung bean flours could be used as a substitute for wheat flour in making biscuits. The quality of the biscuit products made from chayote flour, green bean flour, and both formulations are in the good category with indicators that are acceptable for human consumption because they have high macronutrients and minerals. This also makes it suitable as a healthy food to prevent degenerative diseases.

\section{Acknowledgment}

Thank you to the Head of the Chemistry Education Laboratory at the Faculty of Teacher Training and Educational Science and the Head of the Research Laboratory at the Faculty of Science of Tadulako University, who helped to complete this study.

\section{References}

1. Suhariyanto. Statistik Kesejateraan Rakyat (Welfare Statistics) 2018 Jakarta: BPS Statistics Indonesia; 2018.

2. Al-Marazeeq $\mathrm{KM}$, Angor MM. Chemical characteristic and sensory evaluation of biscuit enriched with wheat germ and the effect of storage time on the sensory properties for this product. Food Nutr Sci. 2017;8(2):189-95. https://doi.org/10.4236/ fns.2017.82012

3. Okpala LC, Ofoedu PI. Quality characteristics of cookies produced from sweet potato and wheat flour blend fortified with Brewer's spent grain flour. Curr Res Nutr Food Sci J. 2018;6(1):113-9. https://doi.org/10.12944/crnfsj.6.1.12

4. Sakung JM, Nurmayanti $Y$, Rahmania M, Fitra $H$. Nutritional evaluation of chayote flour-based biscuits (sechium edule). Indian J Public Health Res Dev. 2020;11(3):2034-8.

5. Substitution of mung bean flour (Vigna radiata) and tuna fish meal (Thunnus $s p$ ) as PMT biscuits for pregnant women on Proximate Levels, Energy Values, Iron Levels, and Organoleptic Quality.

6. Taynath SJ, Singh BK, Jena S, Said PP. Optimization of process variables for petha manufacture from chayote (Sechium edule Sw.). J Food Proc Preserv. 2020;44(11):e14872. https://doi. org/10.1111/jfpp.14872

7. Xie J, Du M, Shen M, Wu T, Lin L. Physico-chemical properties, antioxidant activities and angiotensin-I converting enzyme inhibitory of protein hydrolysates from Mung bean (Vigna radiate). Food Chem. 2019;270:243-50. https://doi. org/10.1016/j.foodchem.2018.07.103

PMid:30174041
8. Sehrawat N, Yadav M, Kumar S, Upadhyay SK, Singh M, Kumar A. Review on health promoting biological activities of mungbean: A potent functional food of medicinal importance. Plant Arch. 2020;20(2):2969-75.

9. Hou $D$, Zhao Q, Yousaf L, Xue $Y$, Shen $Q$. Whole mung bean (Vigna radiata L.) supplementation prevents high-fat dietinduced obesity and disorders in a lipid profile and modulates gut microbiota in mice. Eur J Nutr. 202059(8):3617-34. https:// doi.org/10.1007/s00394-020-02196-2 PMid:32048004

10. Davidson I. Biscuit, Cookie and Cracker Production: Process, Production and Packaging Equipment. Cambridge, Massachusetts: Academic Press; 2018.

11. Branch $S$, Maria $S$. Evaluation of the functional properties of mung bean protein isolate for development of textured vegetable protein. Int Food Res J. 2017;24(4):1595-605.

12. Sakung J, Rahmawati S. Proximate, minerals, and vitamins in chayote flour. Int J Res Pharm Sci. 2020;11(2):2261-4. https:// doi.org/10.26452/ijrps.v11i2.2186

13. Klunklin W, Savage G. Effect of substituting purple rice flour for wheat flour on physicochemical characteristics, in vitro digestibility, and sensory evaluation of biscuits. J Food Qual. 2018;2018:1-8. https://doi.org/10.1155/2018/8052847

14. Šoronja $\square$ Simović $D$, Pajin $B$, Šubarić $D$, Dokić $L$, Šereš $Z$, Nikolić I. Quality, sensory and nutritional characteristics of cookies fortified with chestnut flour. J Food Proc Preserv. 2017;41(1):e12887. https://doi.org/10.1111/jfpp.12887

15. Gyedu-Akoto E, Opoku Stephen Y, Ofosu-Agyei E. Proximate, mineral composition and sensory evaluation of coffee and kola flavoured biscuits. Nutr Food Sci. 2019;49(4):752-61. https:// doi.org/10.1108/nfs-10-2018-0270

16. Eden W, Rumambarsari C. Proximate analysis of soybean and red beans cookies according to the Indonesian national standard. J Phys Conf Ser. 2020;1567:022033. https://doi. org/10.1088/1742-6596/1567/2/022033

17. Dias N, Bandara G. Nutritive assessment of composite flour biscuit incorporated with herbal plant powder. J Food Agric. 2019;12(1):17-28. https://doi.org/10.4038/jfa.v12i1.5217

18. Kumarasamy SM, Dasgupta $P$, Sivasubramaniam $V$ Elangovan A, Ranganathan I. Studies on physiochemical and sensorial properties of biscuits using composite protein rich flours. AIP Conf Proc. 2020;2020:050002. https://doi. org/10.1063/5.0011001

19. Hussain A, Kaul R. Formulation and characterization of buckwheat-barley supplemented multigrain biscuits. Res Nutr Food Sci. 2018;6(3):873-81. https://doi.org/10.12944/ crnfsj.6.3.30

20. Hannah MA, Krishnakumari S. Analysis of mineral elements, proximate and nutritive value in Citrullus vulgaris Schrad. (watermelon) seed extracts. Pharm Innov. 2015;4(8):7-11.

21. Fitriyana L. Fortification of yellow potatoes sweet flour and Jamblang fruit paste (Syzygium cumini) in the making of biscuits on it's sensoric characteristics and mineral content. J Phys Conf Ser. 2019;2019:1-13. https://doi. org/10.1088/1742-6596/1232/1/012008

22. Anitha $\mathrm{S}$, Ramya $\mathrm{H}$, Ashwini $\mathrm{A}$. Effect of mixing pumpkin powder with wheat flour on physical, nutritional and sensory characteristics of cookies. Int J Commun Syst. 2020;8(4):1030-5.

23. Linlawan S, Patcharatrakul T, Somlaw N, Gonlachanvit S. Effect of rice, wheat, and mung bean ingestion on intestinal gas production and postprandial gastrointestinal symptoms in non-constipation irritable bowel syndrome patients. Nutrients. 2019;11(9):2061. https://doi.org/10.3390/nu11092061 PMid:31484315

24. Chen $\mathrm{CH}$, Lin $\mathrm{CL}$, Kao $\mathrm{CH}$. Irritable bowel syndrome is associated with an increased risk of dementia: A nationwide 
population-based study. PLoS One. 2016;11(1):e0144589. https://doi.org/10.1371/journal.pone.0144589

PMid:26731277

25. Wani IA, Andrabi SN, Sogi DS, Hassan I. Comparative study of physicochemical and functional properties of flours from kidney bean (Phaseolus vulgaris L.) and green gram (Vigna radiata L.) cultivars grown in Indian temperate climate. Legume Sci. 2020;2(1):e11. https://doi.org/10.1002/leg3.11

26. Gupta S, Hawk T, Aggarwal A, Drewnowski A. Characterizing ultra-processed foods by energy density, nutrient density, and cost. Front Nutr. 2019;6:70. https://doi.org/10.3389/ fnut.2019.00070

PMid:31231655

27. Ekafitri $R$, Isworo R. The utilization of beans as protein source for emergency food. J Pangan. 2014;23(2):134-45.

28. Feyera M. Review on some cereal and legume based composite biscuits. Int J Agric Sci Food Technol. 2020;6(2):101-9.

29. Adeola AA, Ohizua ER. Physical, chemical, and sensory properties of biscuits prepared from flour blends of unripe cooking banana, pigeon pea, and sweet potato. Food Sci Nutr. 2018;6(3):532-40. https://doi.org/10.1002/fsn3.590

PMid:29876103

30. Greer RC, Marklund M, Anderson CA, Cobb LK, Dalcin AT, Henry $M$, et al. Potassium-enriched salt substitutes as a means to lower blood pressure: Benefits and risks. Hypertension. 2020;75(2):266-74. https://doi.org/10.1161/ hypertensionaha. 119.13241

\section{PMid:31838902}

31. Filippini T, Naska A, Kasdagli MI, Torres D, Lopes C, Carvalho C, et al. Potassiumintake and blood pressure: A dose-response meta-analysis of randomized controlled trials. J Am Heart Assoc. 2020;9(12):e015719. https://doi.org/10.1161/jaha.119.015719 PMid:32500831

32. Baloš MŽ, Jakšić $S$, Knežević $S$, Kapetanov M. Electrolytessodium, potassium and chlorides in poultry nutrition. Arch Vet Sci. 2016;9(1):31-42. https://doi.org/10.46784/e-avm.v9i1.95

33. Bakare AH, Adeola AA, Otesile I, Obadina AO, Afolabi WA, Adegunwa $\mathrm{MO}$, et al. Nutritional, texture, and sensory properties of Composite biscuits produced from breadfruit and wheat flours enriched with edible fish meal. Food Sci Nutr. 2020;8(9):1-21. https://doi.org/10.1002/fsn3.1919

34. Onwurafor E, Uzodinma E, Uchegbu N, Ani JC, Umunnakwe IL, Ziegler G. Effect of malting periods on the nutrient composition, antinutrient content and pasting properties of mungbean flour. AgroScience. 2020;19(1):18-24. https://doi.org/10.4314/as.v19i1.3

35. Onwurafor EU, Uzodinma EO, Chikwendu JN. Effect of incorporation of unripe plantain and mung bean malt flours on wheat flour on the chemical, physical and sensory properties of cookies. Int Food Res J. 2019;26(3):959-67.

36. Zakaria, Rauf S, Salim A, Rahman N, Bohari. Development of instant powder with the addition of Moringa oleifera leaf powder as complementary food for infants 6-12 months old. Syst Rev Pharm. 2020;11(7):61-4. 